\title{
RECONNOITERING THE INTERVENING ROLE OF DYNAMIC CAPABILITIES BETWEEN HIGH-PERFORMANCE WORK SYSTEMS AND INNOVATION PERFORMANCE
}

\author{
Naveed Mushtaq ${ }^{1^{*}}$, Aziz Javeed ${ }^{2}$, Ahmed Saeed $^{3}$, Mohsin Altaf ${ }^{4}$ \\ ${ }^{1 *}$ Assistant Professor, University of Sargodha, Pakistan; ${ }^{2}$ Assistant Professor, IBA Gomal University, Pakistan; \\ ${ }^{3}$ Assistant Professor, University of Sargodha Sub-Campus Bhakar, Pakistan; ${ }^{4}$ Assistant Professor, University of Lahore, \\ Pakistan. \\ Email: "naveed.mushtaq@uos.edu.pk
}

Article History: Received on $10^{\text {th }}$ June 2021, Revised on $15^{\text {th }}$ June 2021, Published on $24^{\text {th }}$ June 2021

\begin{abstract}
Purpose of the study: This study explores the Impact of High-Performance Work System practices (HPWS), on innovation performance, through the intervening role of dynamic capabilities and innovation culture among the rapidly growing cement industry of Pakistan, which is the backbone of Pakistan's construction industry.
\end{abstract}

Methodology: This is a self-administrative survey, and data were analyzed using Smart PLS 3.0, SPSS.

Main Findings: HPWS has a positive impact on a firm's innovation performance. Furthermore, dynamic capabilities mediated the association between HPWS and innovation performance.

Applications of this study: The study is essential for the cement industry, where traditional HRM has long been applied. Using HPWS would create a more innovative environment and establish dynamic capabilities that can trigger innovations such as administrative, incremental, radical, and marketing in the face of dynamic customer demands.

Novelty/Originality of this study: This study has enriched our understanding of how organizations can improve their innovation performance in a complex and ambiguous environment, which is crucial to gaining competitive advantages. This study also suggests that developing a system of HPWS practices in organizations, particularly the cement industry, will help the organizations flourish and stay competitive in the marketplace and help elicit the right employee attitudes by fully mediating dynamic capabilities. Therefore, organizations should establish developed HPWS and create an innovation culture that will ultimately benefit the organization creates an innovation culture.

Keywords: High-Performance Work Systems, Dynamic Capabilities, Innovation Performance, Self-administrative Survey.

\section{INTRODUCTION}

The world has been transformed into an era of globalization and resource assimilation due to robust competition, rapid innovation, and changes and innovations (Muisyo \& Qin, 2021). Association between HRM and firm performance has been widely discussed in the literature by many researchers (Lu, Chen, Huang, \& Chien, 2015). Effective utilization of human resources guarantees the timely achievement of organizational objectives (Al-Taii, Ismael, \& Khudhur, 2020). It adds to firm performance, which is the ability to anticipate achieving the firm's goals and accomplishment of its objectives. Firm performance is a measure of both financial and non-financial measures. Financial measures indicate economic measures, while non-financial measures are market quality, satisfaction, employee retention, and market effectiveness (Barker \& Mone, 1994). In the current research scenario, many organizations and researchers tried to investigate the association between HRM systems and HRM functions like selection, placement, promotion, and retention. In HRM, researchers rely upon resource-based views to demonstrate the impact of strategic HRM and HRM systems on organizational performance (Zehir, Gurol, Karaboga \& Kole, 2016). A high-performance work system (HPWS) is the core emerging area of HRM. HPWS includes interrelated human resource practices that enable organizations to achieve their objectives effectively and efficiently.

The direct impact of HPWS on organization innovation performance has been tested by the researchers like Shih, Chiang, and Hsu (2013), while indirect effects with the help of extensive constructs still need researchers' attention. Few researchers from the South Asian context have explored the direct impact of HPWS on outcome variables like HR practices, firm performance, and organizational culture (Lin \& Liu, 2016), but research in the Asian context to test the direct impact of HPWS on dynamic capability domain, especially in the sector of cement industry, is still a black box from the theoretical perspective of RBV-DC. Dynamic capabilities include the firm's integration abilities, modify and reconfigure the firm's internal and external competencies to combat rapid technological, mechanical, and human resources (Medeiros, Christino, Gonçalves \& Gonçalves, 2020). Different dynamic capabilities may include operational capabilities and tactical capabilities (Eisenhardt \& Martin, 2000). In this study, a different perspective of dynamic capabilities, the multi-dimensional dynamic capabilities, a higher-order construct comprising coordinating, learning, and strategic competitive capabilities, is adopted (Datta, Guthrie \& Wright, 2005). Firms operating in developed and developing countries rapidly utilize their dynamic capabilities to compete in international competition. The ability to generate revenue through the sale of new or improved goods or services is a fast and necessary condition for companies seeking to compete sustainably in the global marketplace. The emerging economies are trying to create that kind of 
competitive framework where HPWS and innovation performance with the help of advanced technology and human capabilities may provide organizationally.

Researchers hope this research will help us understand how HRM and employee engagement systems can drive innovation performance. In particular, this research will contribute to ongoing debates about the nature of highperformance work systems and examine whether there is a "best way" to manage companies - or, more specifically, employees of these companies - to get a higher advantage. Ultimately, the study aims to link the impact of this company-level research survey to the significant challenges facing today's Pakistani companies and policymakers. Workforce skills are essential because they include "communication skills, skills to interact with customers, creative thinking and problem-solving skills, and entrepreneurial thinking". In the context of the South Asian paradigm, it is empirically proven that HRM practices help to create and retain innovation culture in the organization and subjective HRM practices help in retaining employees to resolve this issue of high turnover in the context of Pakistan. Innovation culture has the potential to strengthen the organization's dynamic capabilities and enhance firm innovation performance.

\section{LITERATURE REVIEW}

\section{High-Performance Work System and Firm Innovation Performance}

High-performance work systems (HPWS) are a core area of HRM that attracts the attention of recent researchers towards the retention of sustainable competitive advantage. HPWS can be defined as the combination of HRM practices that are designed to attract the attention of qualified/ skilled employees, alignment of Commitment, and productivity in a way that the employee becomes a source of competitive advantage for the organization. Sustainable competitive advantage based on resources and knowledge-based view remained a dream for every organization. The concept of HPWS is derived from the concept of the organizational resource-based view (Özçelik, Aybas \& Uyargil, 2016). It includes the dimensions like high-performance work practices, high involvement, higher level of Commitment, and loyalty (Heffernan, \& Dundon, 2016; Boxall \& Macky, 2007) have defined (HPWS) is composed of highly-skilled, brilliant, and highly devoted employees that can elevate an organizations performance. It is pertinent to mention here that which practices constitute HPWS is yet a debate in academic literature. Kintana, Alonso, and Olaverri (2006) provided an extensive list from academic papers of possible factors that studies have used as factors of HPWS that include but not limited to "staffing procedures, stability in the employment relation, compensation schemes linked to group performance, above-average compensation, flexible job assignments (job rotation), self-directed work teams, extensive training, and a high level of communication and fair treatment through all organizational levels. HPWS is positively associated with the organization's performance and organizational culture. It has been empirically tested in different contexts by many famous researchers like Michaelis, Wagner, and Schweizer (2015). HPWS are associated with the competitive advantage and accompanied by the organization's overall success both, monetary and non-monetary. In the context of recent findings, it has been empirically tested and widely proved that HPWS enhances organization as well as employee commitment, reduces absenteeism, turnover, and low psychological well-being (Huang, Ahlstrom, Lee, Chen \& Hsieh, 2016; Zhang, Zhu, Dowling \& Bartram, 2013). Sustaining in the global business has become a challenging job for which organizations are striving hard to adopt those innovative practices that could enhance a firm's innovation performance, as it is being believed universally now that innovation is the only guarantee to future sustainability (Kuzma, Padilha, Sehnem, Julkovski \& Roman, 2020). To accomplish this goal, HR needs to be efficient as it has a direct role in the firm's innovation performance (Sriviboon, 2020). HR practices or HR systems or Commitment based HR systems could motivate and trigger innovation due to the provision of a supportive environment created by the HR system. Hence, and alignment among business strategy, HRM strategy, and HRM practices become a central concern, and the adoption of HPWS is one good example of this alignment. HPWS is considered a potential determinant of competitive advantage (Guthrie, Flood, Liu, \& MacCurtain, 2009), while Abbasi, Shabbir, Abbas, and Tahir (2020) emphasized practices vary in literature from author to author. Still, one consensus has been reached amongst these researchers that HPWS do activate innovation. Macky and Boxall (2007) also affirmed through empirical research that the HR system comprises "flexible jobs, empowerment, teamwork, long-term skill-oriented resourcing, extensive and long-term training, broad career opportunities, behavior-based appraisal, variable reward system" is positively associated with the firm's innovation performance. (Chen \& Huang, 2009) also emphasized that a good set of HR practices (HPWS) develops a more knowledgeable and well-trained workforce for the organization. This workforce is then motivated enough to use their knowledge, skills, and abilities to generate different innovations (Bhatti, Zakariya, VrontisSantoro, \& Christofi, 2020). Though various scholars believe that this relationship between certain HR practices and radical innovation is negative, some specific HR practices require innovation activities to affect the organization positively. The skills, knowledge, and capabilities of employees get enhanced by implementing HR practices that involve Commitment in them (Lepak \& Snell, 2002). Research says that a bundle of HR practices is more effective than a single HR practice. Firm innovation performance includes the human resource practices linked with Commitment (Dewinne \& Sels, 2010). The individual HR practice does not affect the firm's innovation activities as much as a bundle of related HR practices does (Laursen \& Foss, 2003). If an organization selects employees based on their future potential and development, it helps develop process innovation activities (Al-Ajlouni, 2020; Ceylan, 2013). Several studies say that there is a slight amount of linkage between HR practices and marketing innovation activities. For instance, Chaston, Badger, and Sadler-Smith (2000) found the connection between HR practices (bundle) and the firm's innovative marketing styles. Therefore, considering HPWS as a higher-order construct, the first hypothesis is proposed as under: 
H1: HPWS systems are positively related to a firm's Innovation Performance.

\begin{tabular}{|c|c|c|}
\hline HPWS & Dynamic Canohility & \\
\hline $\begin{array}{c}\text { Ability Enhancing } \\
\text { Practices }\end{array}$ & $\begin{array}{l}\text { Sensing Capability } \\
\text { Seizing Capability }\end{array}$ & $\begin{array}{c}\text { Innovation Performance } \\
\text { Incremental Product Innovation }\end{array}$ \\
\hline $\begin{array}{c}\text { Motivation Enhancing } \\
\text { Practices } \\
\text { Opportunity Enhancing } \\
\text { Practices }\end{array}$ & $\begin{array}{l}\text { Re-Configuration } \\
\text { Capability } \\
\text { (Higher Order } \\
\text { Construct) }\end{array}$ & $\begin{array}{l}\text { Incremental Process Innovation } \\
\text { Radical Product Innovation } \\
\text { Radical Process Innovation } \\
\text { Marketing Innovation }\end{array}$ \\
\hline
\end{tabular}

Figure 1: Research Framework

Source: Prepared by Author

\section{High-Performance Work System and Firm Dynamic Capabilities}

The link between high-performance work systems and dynamic enterprise capabilities has been widely discussed and empirically tested in the field of HRM. Teece, Pisano, and Shuen (2007) used a different approach to explain the phenomenon, how innovation leads to the competitive advantage of a firm. In his view, these dynamic capabilities are an essential pre-requisite based on the changing customer demands, new technological opportunities in the market, nurturing ecosystem it subjugates, and development of new products and processes that can add value. He also emphasized that these capabilities upgrade the old resource-based and keep on changing according to environmental opportunities. In other words, with every changing opportunity, a different set of dynamic capabilities will be adopted that would reconfigure the organizational routines in pursuit of that opportunity (innovation) which is necessary for the firm's development of the organization (Ambrosini \& Bowman, 2009). For this very reason highly skilled, knowledgeable, and well-integrated employee pool is the first and foremost priority of any firm. SHRM, which comprises an ideal set of HR practices answers, is the answer to dynamic capability development. SHRM looks at it as a bundle, but not all bundles as per se enhance a firm's competitive advantage, yet they have a more significant role towards the firm's dynamic capabilities (Morris et al, 2009). Many researchers came up with the findings that HPWS is negatively associated with the firm dynamic capacity of the firm but in the context of the American and South Asia paradigm.

Therefore, the second hypothesis is proposed as under:

H2: High-performance work systems are positively related to firm DC.

\section{Dynamic Capabilities \& Firm's Innovation Performance}

Dynamic capabilities are extracted from the resource-based view of the firm. Dynamic capabilities emphasize firms' ability to react adequately, and timely external changes require the combination of different capacities. These capabilities may include advancing technological and rapid modifications according to rapid technological advancement and validations. As for as the taxonomy of dynamic capabilities is concerned, past researchers have shown divergent views. In this research, the dynamic capability is divided into sub-dimensions namely sensing capability, learning capability, and reconfiguring capability, and is adapted from the work of (Xin, Song, Fuji \& Zexia, 2018).

The direct impact of dynamic capabilities on innovation strategies has been investigated by Wang et al., (2019) According to them, if a firm's strategic orientation is towards innovation, all of its resources are also aligned to developing necessary capabilities that are dynamic and that can result in higher levels of sustainability in new products. Hagedoorn and Duysters (2002) also stress that a firm having dynamic capability (to innovate) leads towards the development of new processes and products. Based on a dataset of top 500 manufacturing established firms in (Chiu, Chi, Chang, \& Chen, 2016) among Taiwanese firms concluded that that four types of dynamic capabilities and radical product innovation are positively associated sequentially and structurally. Moreover, organizations are always in a continuous hunt for external market opportunities that can generate profits for the firms to sustain competitiveness. Therefore, firms need to develop those capabilities through which they can spot the changing market trends, consumer preferences, and explore future markets. This market hunt opens doors to new knowledge related to consumers, supplier's technology, intermediaries, consumer demands and opens new avenues for innovation at the internal firm level. This also helps the enterprise to adapt to new changes and rebuild its resource base to capture emerging market opportunities.

Secondly, firms with better learning capability not only become the first mover in the market with new innovative products and services but at the same time are in a much better position to reconfigure its resources base in light of the 
accumulated knowledge that it has gathered in the learning process. This assimilated information then acts as a stimulus for new idea creation and leads to better innovations. Lastly, reconfiguration capability is a unique dynamic capability as it makes the organization take strategic decisions in terms of re-allocating its in-house as well external resources in the best interest of the consumers to gain a competitive edge and helps an organization to touch the new height of innovation. Based upon the above literature following set of working hypotheses is proposed.

H3: Firm DC is positively related to innovation performance.

\section{Mediating Effect of Dynamic Capabilities}

Resource-based views provide the foundation for the essence of dynamic capabilities and innovation performance. The resource-based view integrates four major areas of the firm, which has been defined by Barney (1994). Barney came up with an idea that resources and capabilities support and deliver a durable competitive advantage to the organization. Additionally, he also introduced the term VRIN which was the abbreviation of valuable, rare, imperfectly imitable, and non-sustainable. Dynamic capabilities are generally understandable in the context of the organization's overall portfolio. Teece et al., (2007) termed it as the micro foundation and higher-order capabilities and empirically proved that dynamic capabilities are positively associated with the VRIN model that ultimately supports innovation and sustainable competitive advantage. The magnitude and strength of dynamic capabilities are aligned with the organization's available resources and their effective utilization. Dynamic capabilities are multi-faceted, and the firm could not be strong without incorporating its dimensions (Helfat \& Raubitschek, 2018). restrict the definition of dynamic capabilities up to managerial skills only and their proper utilization. From the theoretical perspective of RBV and its extension DC, resources are important but not sufficient enough; firms need to have dynamic capabilities to enhance their performance. Hence when all the three dimensions of dynamic capability are in place the sensing will grasp the opportunity, learning will update the knowledge resource base and develop new skills while reconfiguring will re-integrate company assets in the right direction for production of good or service for the consumers to enabling the enterprise to achieve sustainable growth in a dynamic environment. Therefore, we propose the next set of working hypotheses as:

H4: DC mediates the relationship between High-Performance Work System and innovation performance.

\section{METHODOLOGY}

\section{Population}

The population of this study consists of cement manufacturers listed on Karachi Stock Exchange. There are 22 listed cement manufacturers on Karachi Stock Exchange, and all were included as the population of the study. The unit of analysis is the top-level managers such as marketing, innovation, product development managers, operation managers, etc. in cement manufacturing companies. Personally, administrative instruments were designed to get responses from the expected respondents of this study.

\section{Sample}

The most suitable methods for the researcher were to use convince sampling technique. For this purpose, 300 questionnaires were distributed among employees working in government and the private sector cement manufacturing organizations listed on Karachi Stock Exchange. Convenience sampling technique was used to collect data due to adequate response and ease of access from the employees of these manufacturing concerns. Thanks to the direct contact of the researchers, the convenience of sampling are useful with the help of the individual administrative questionnaire, and all inquiries from the respondents are resolved on the spot.

\section{Research Design}

Since this study is based on a quantitative approach, a questionnaire-based technique was used. Cross-sectional data were collected from individual administrative questionnaires from employees of these manufacturing issues. Crosssectional surveys are a useful tool for data collection due to the personal connections and presence of researchers.

\section{Data Collection}

The data (main properties) comes from the Cement manufacturers listed on Karachi Stock Exchange. The questionnaire was distributed in person, and the responses were collected through questionnaires. These questionnaires are distributed to all departments of the manufacturing sector, such as the human resources department, the administration department, the customer, and the customer service department, through personal contact.

\section{Variable Measurement}

High-performance work systems were adopted from Collins and Smith (2006), having three sub-dimensions comprising of 16 items to measure firm-level namely selection, incentives, and training and development policies. Following the literature of SHRM. The dynamic capabilities scale was adopted from Heider, Gerken, Van Dinther, and Hülsbeck (2021). The innovation performance dimensions measures were mainly adapted from the previous studies. 


\section{RESULTS/FINDINGS}

\section{DATA ANALYSIS AND RESULTS}

The researchers used Smart PLS version 3.0.M3 to analyze the two phases of data related to the measurement model and the structural model. When the model is complex, the sample size is very small, or does not meet the assumption of normality, it is recommended to use the Smart PLS structural equation modeling technique. For the current study, the model is complex, and the sample size is small $(\mathrm{N}=159)$. PLS-SEM provides an advantage for reliable model estimation in small samples. The path model was developed and tested using the statistical software application SMART PLS 3.0 (Ringle, Wende \& Will, 2005) to measure the causal model. Path model evaluation is performed in two phases: measurement models and structural models.

\section{Response Rate:}

Total questionnaires were sent 250 questionnaires, 159 were filled through direct interaction of the researcher with the respondents. The response rate was $76.8 \%$.

\section{Measurement model}

CFA (confirmatory factor analysis) has been applied to establish how well the measured variables represent the number of constructs. The CMB (ratio of principal factor variance to total variance) was found to be $35.56 \%$ which is less than 50\%. as recommended by Podsakoff, MacKenzie, Lee, and Podsakoff (2003), Cronbach's is between 0.702 and 0.885 , and CR values are also within the limits as prescribed by (Fornell \& Larcker, 1981) while Nunnally (1994), also recommended values as low as 0.6 as acceptable as shown in Table 1. Furthermore, all loadings were above 0.5 (more than 50\%) (Hair, Black, Babin, Anderson \& Tatham, 2006) Table 1 and HTMT value is below 0.90, discriminant validity has been upheld between two reflective constructs (Hair, Hult, Ringle \& Sarstedt, 2016) as shown in Table 2. The VIF was found to be less than 2 as per the established criterion of (Hair et al., 2016) hence the measurement model shows a good fit.

Table 1: Loadings, AVE, Cronbach's Alpha \& CR

\begin{tabular}{|c|c|c|c|c|c|}
\hline & & $\begin{array}{l}\text { Factor } \\
\text { Loadings }\end{array}$ & $\begin{array}{l}\text { Cronbach's } \\
\text { Alpha }\end{array}$ & $\begin{array}{l}\text { Composite } \\
\text { Reliability }\end{array}$ & $\begin{array}{l}\text { Average } \\
\text { Variance } \\
\text { Extracted } \\
\text { (AVE) } \\
\end{array}$ \\
\hline \multirow[t]{16}{*}{$\begin{array}{l}\text { Organic } \\
\text { (Second } \\
\text { Construct) }\end{array}$} & & 0.856 & 0.864 & 0.58 & 0.655 \\
\hline & Ability Enhancing Practices & & 0.730 & 0.820 & 0.520 \\
\hline & AERP1 & 0.76 & & & \\
\hline & AERP2 & 0.62 & & & \\
\hline & AERP4 & 0.73 & & & \\
\hline & AERP5 & 0.79 & & & \\
\hline & Motivation Enhancing & & 0.700 & 0.844 & 0.518 \\
\hline & ME1 & 0.70 & & & \\
\hline & ME3 & 0.75 & & & \\
\hline & ME4 & 0.74 & & & \\
\hline & ME5 & 0.76 & & & \\
\hline & Opportunity enhancing practices & & 0.870 & 0.802 & 0.622 \\
\hline & OEP1 & 0.77 & & & \\
\hline & OEP2 & 0.80 & & & \\
\hline & OEP3 & $0 . .86$ & & & \\
\hline & OEP4 & 0.72 & & & \\
\hline \multirow[t]{5}{*}{$\begin{array}{lr}\text { Dynamic } & \text { Capability } \\
\text { (Second } & \text { Order } \\
\text { Construct) } & \\
\end{array}$} & & & 0.886 & 0.870 & 0.620 \\
\hline & Sensing Capability & & 0.843 & 0.882 & 0.516 \\
\hline & $\mathrm{SC} 1$ & 0.72 & & & \\
\hline & $\mathrm{SC} 2$ & 0.71 & & & \\
\hline & SC3 & 0.77 & & & \\
\hline
\end{tabular}




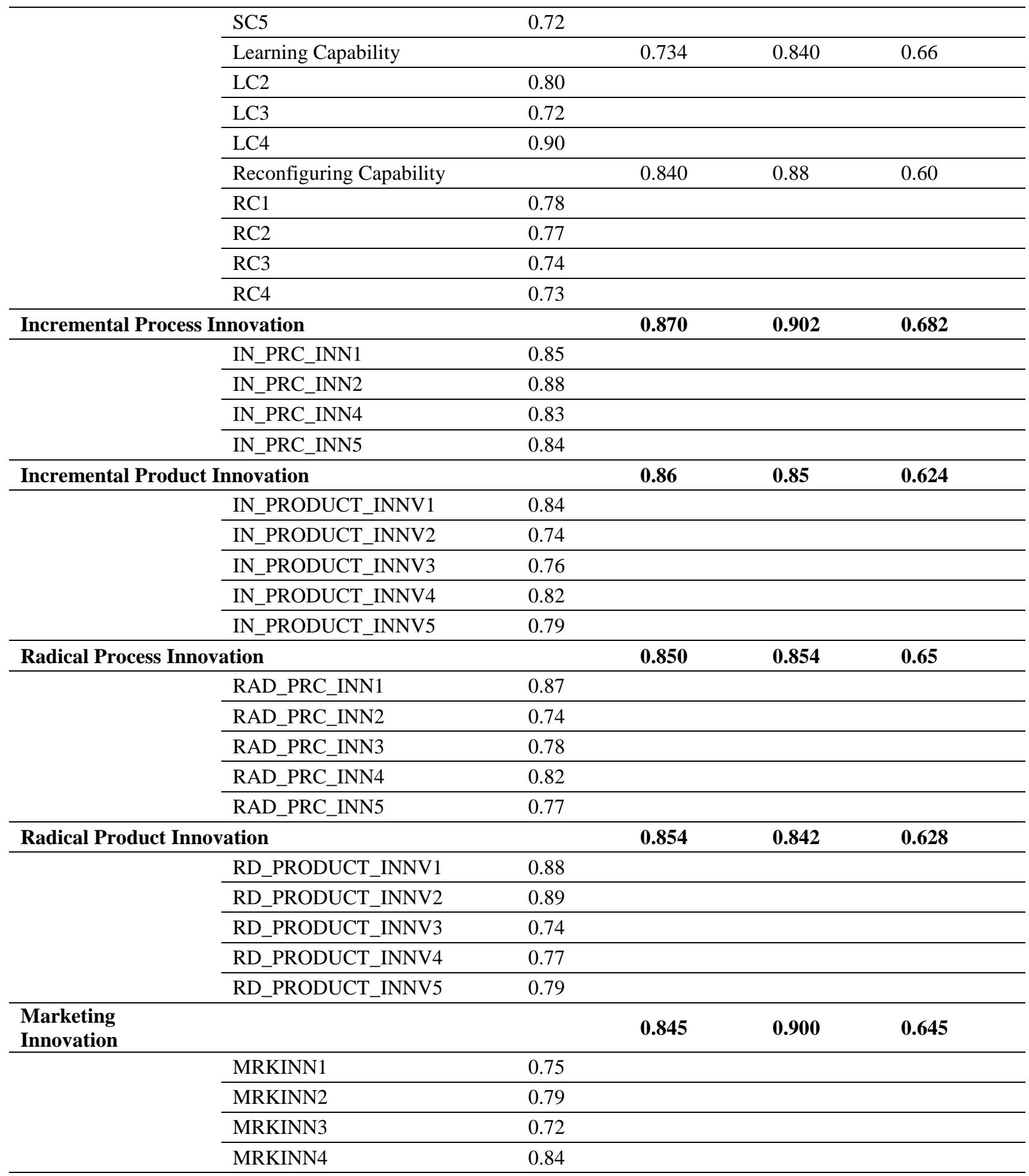

Structural Model Analysis

Table 2: Structural Model Results

\begin{tabular}{llll}
\hline & $\begin{array}{l}\text { Original } \\
\text { Sample (O) }\end{array}$ & T.Statistics & Results \\
\hline HPWS -> Incremental Product Innovation & 0.621 & 6.908 & $* * *$ \\
\hline HPWS-> Incremental Process Innovation & 0.426 & 3.376 & $* * *$ \\
\hline HPWS -> Radical Process Innovation & 0.000 & 0.004 & NS \\
\hline HPWS -> Radical Product Innovation & 0.223 & 2.530 & $* * *$ \\
\hline HPWS -> Marketing Innovation & 0.321 & 2.672 & $* * *$ \\
\hline
\end{tabular}




\begin{tabular}{llll}
\hline Dynamic Capability -> Incremental Product Innovation & 0.189 & 1.710 & $*$ \\
\hline Dynamic Capability -> Incremental Process Innovation & 0.748 & 13.196 & $* * *$ \\
\hline Dynamic Capability -> Radical Process Innovation & 0.467 & 4.751 & $* * *$ \\
\hline Dynamic Capability -> Radical Product Innovation & 0.334 & 2.717 & $* * *$ \\
\hline Dynamic Capability -> Marketing Innovation & 0.357 & 3.822 & $* * *$ \\
\hline
\end{tabular}

$* \mathrm{P}<0.10 ; * * \mathrm{p}<0.05 ; * * * \mathrm{p}<0.01 ; \mathrm{NS}$ : Not Significant

The indirect effect of HPWS on incremental process, incremental product, marketing, and radical product innovation was exerted through dynamic capability with $(\beta=.0 .426, p<0.01),(\beta=.621, p<0.01),(\beta=.223, p<0.01),(\beta=.254, p<$ $0.01),(\beta=.549, \mathrm{p}<0.01)$, respectively while the direct paths from HPWS to incremental process, incremental product, marketing, radical process, and radical product innovation were found to non-significant thus making indirect only effect. The indirect effect of HPWS on radical product innovation is found to be significant, and the direct path was also found to be insignificant hence No Mediation was the outcome.

\section{Mediating Effects}

Table 3 below shows the indirect effect values of the mediation effect.

Table 3: Mediation Effect Results

\begin{tabular}{|c|c|c|c|c|}
\hline & $\begin{array}{l}\text { Original } \\
\text { Sample }(\mathrm{O})\end{array}$ & $\begin{array}{l}\mathrm{T} \\
\text { Statistics }\end{array}$ & RESULTS & Mediation \\
\hline $\begin{array}{l}\text { Dynamic Capability mediates the relationship between } \\
\text { HPWS and Incremental Product Innovation } \\
\text { performance }\end{array}$ & 0.621 & 6.908 & $* * *$ & $\begin{array}{l}\text { Full } \\
\text { Mediation }\end{array}$ \\
\hline $\begin{array}{l}\text { Dynamic Capability mediates the relationship between } \\
\text { HPWS and Incremental Process Innovation } \\
\text { performance }\end{array}$ & 0.426 & 3.376 & $* * *$ & $\begin{array}{l}\text { Full } \\
\text { Mediation }\end{array}$ \\
\hline $\begin{array}{l}\text { Dynamic Capability mediates the relationship between } \\
\text { HPWS and Radical Product Innovation performance }\end{array}$ & 0.000 & 0.004 & NS & $\begin{array}{l}\text { Not } \\
\text { Significant }\end{array}$ \\
\hline $\begin{array}{l}\text { Dynamic Capability mediates the relationship between } \\
\text { HPWS and Radical Process Innovation performance }\end{array}$ & 0.549 & 16.239 & $* * *$ & $\begin{array}{l}\text { Full } \\
\text { Mediation }\end{array}$ \\
\hline $\begin{array}{l}\text { Dynamic Capability mediates the relationship between } \\
\text { HPWS and Marketing Innovation performance }\end{array}$ & 0.223 & 2.530 & $* * *$ & $\begin{array}{l}\text { Full } \\
\text { Mediation }\end{array}$ \\
\hline
\end{tabular}

$* \mathrm{P}<0.10 ; * * \mathrm{p}<0.05 ; * * * \mathrm{p}<0.01 ; \mathrm{NS}$ : Not Significant

\section{DISCUSSION/ANALYSIS}

Since the integrated and extended models are used for theoretical evidence in research, it is necessary to explore empirical evidence. Using the key variables used in the model, the study attempts to test the impact of HPWS on innovation performance while exploring the mediating role of dynamic capabilities and moderating the impact of innovation culture. The outcome of the current study is strongly supported by past researchers' findings of Zanko, Badham, Couchman, and Schubert (2008) where they found a strong association between the bundle of HR practices and firm innovation performance. The results of this study show that there exists a positive association between HPWS and dynamic capabilities. This association concluded that effective HPWS will enhance and support firm dynamic capabilities. If there exists no HPWS in the organization then ultimately no dynamic capabilities will exist in the organization. Ferreira and Coelho, (2020) also found a significant association between firm dynamic capabilities and innovation performance. Giniuniene and Jurksiene (2015) empirically tested the positive association between dynamic capabilities and innovation performance. Naldi, Wikström, and Von-Rimscha (2014) in their study of the European audiovisual production industry found that dynamic capabilities have a positive impact on a firm's innovation performance. Hence the results of this study support the argument that dynamic capabilities not only enhance the firm innovation performance but also reshapes the firm's current resources for future innovations. Sensing the market demand is not sufficient as dynamic capabilities reconfigure our resource base to seize the market opportunity and obtain a strategic fit. The mediating association of firm dynamic capabilities exists in this hypothetical framework. The results of this study reveal that dynamic capabilities successfully mediated the association between HPWS and firm innovation performance dimensions except for radical product innovation performance. Parameters tested that dynamic capabilities will strengthen the association between HPWS and firm innovation performance. 


\section{CONCLUSION}

This study was conducted to investigate the impact of HPWS on innovation performance exploring the mediating role of dynamic capabilities and moderating impact of innovation culture. Innovation performance has three dimensions; radical product innovation, process innovation, and marketing innovation. The results proposed that there exists a correlation among all the variables, which means that if there exists HPWS in the organization among the employees, then the dynamic capabilities will ultimately increase, and if dynamic capabilities exist, then innovation culture and innovation performance will also increase. The results also suggest that if there is a positive and constructive dimension in the HPWS level, then the ratio of dynamic capabilities will increase. HPWS is a fundamental factor within the organization and a higher management effort that enables them to execute efficiently for the benefit of the organization, and this concept can mediate the relationship between the HPWS and innovation performance. Similarly. The direct impact of dynamic capabilities on innovation performance has a positive association in the literature of HRM.

\section{LIMITATION AND STUDY FORWARD}

The current study is not without limitations. First, other intervening variables may exist aside from the dynamic capabilities in the HPWS-firm innovation relationship. We encourage more systematic development to better specify the causal mechanisms through which HPWS impacts firm outcomes. This entails more systematic observation and theory building concerning the mechanisms through which HPWS influences firm innovation. One important aspect of this linkage specification is the AMO framework of SHRM. Secondly, the role of other moderating variables such as innovative climate, training, green innovative work behavior can enhance the current model. Other limitations concern the study's small sample size, single-industry focus, and cross-sectional design. Future research could undertake multilevel studies to capture a more comprehensive picture of the links between individual HPWS and different dynamic capabilities and muti- innovation performance dimensions. The findings of this study provide empirical evidence for a chain of mechanisms through which HPWS, Dynamic capabilities, and firm innovations are linked.

\section{ACKNOWLEDGEMENT}

The present research was conducted without taking any kind of financial help from institutions.

\section{AUTHORS CONTRIBUTION}

Naveed Mushtaq conceptualized the study and did work on the first and last section of this article while Aziz Javeed wrote the methodology. Ahmed Saeed completed the introduction of the article, and Mohsin Altaf reviewed the literature and assisted in results and findings.

\section{REFERENCES}

1. Abbasi, S. G., Shabbir, M. S., Abbas, M., \& Tahir, M. S. (2020). HPWS and knowledge sharing behavior: The role of psychological empowerment and organizational identification in public sector banks. Journal of Public Affairs, 20(3), 1-8. https://doi.org/10.1002/pa.2512

2. Al-Ajlouni, M. I. (2020). Can high-performance work systems (HPWS) promote organizational innovation? Employee perspective-taking, engagement and creativity in a moderated mediation model. Employee Relations, 43(2), 373-397. https://doi.org/10.1108/ER-09-2019-0369

3. Al-Taii, M. A., Ismael, H. K., \& Khudhur, S. A. (2020). The role of human resources maintenance in achieving organizational agility. TANMIYAT AL-RAFIDAIN, 39(125), 43-62. https://doi.org/10.33899/tanra.2020.164504

4. Ambrosini, V., \& Bowman, C. (2009). What are dynamic capabilities and are they a useful construct in strategic management? International Journal of Management Reviews, 11(1), 29-49. https://doi.org/10.1111/j. 1468-2370.2008.00251.x

5. Barker, V. L., \& Mone, M. A. (1994). Retrenchment: cause of turnaround or consequence of decline?. Strategic management journal, 15(5), 395-405. https://doi.org/10.1002/smj.4250150506

6. Barney, U. (1994). Human resources and sustained competitive advantage: a resource-based perspective. International Journal of Human Resource Management, 5(2), 301-326. https://doi.org/10.1080/ $\underline{09585199400000020}$

7. Bhatti, S. H., Zakariya, R., Vrontis, D., Santoro, G., \& Christofi, M. (2020). High-performance work systems, innovation and knowledge sharing. Employee Relations, 43(2), 438-458. https://doi.org/10.1108/ER-10-2019$\underline{0403}$

8. Boxall, P., \& Macky, K. (2007). High-performance work systems and organizational performance: Bridging theory and practice. Asia Pacific Journal of Human Resources, 45(3), 261-270. https://doi.org/10.117 7/1038411107082273.

9. Ceylan, C. (2013). Commitment-based HR practices, different types of innovation activities and firm innovation performance. The International Journal of Human Resource Management, 24(1), 208-226. https://doi.org/10.1080/09585192.2012.680601

10. Chaston, I., Badger, B., \& Sadler-Smith, E. (2000). Organizational learning style and competences: a comparative investigation of relationship and transactionally orientated small UK manufacturing firms. European Journal of Marketing, 34(5), 625-642. https://doi.org/10.1108/03090560010321965 
11. Chen, C. J., \& Huang, J. W. (2009). Strategic human resource practices and innovation performance: The mediating role of knowledge management capacity. Journal of Business Research,62(1), 104-114. https://doi.org/10.1016/j.jbusres.2007.11.016

12. Chiu, W. H., Chi, H. R., Chang, Y. C., \& Chen, M. H. (2016). Dynamic capabilities and radical innovation performance in established firms: a structural model. Technology Analysis \& Strategic Management, 28(8), 965-978. https://doi.org/10.1080/09537325.2016.1181735

13. Collins, C. J., \& Smith, K. G. (2006). Knowledge exchange and combination: The role of human resource practices in the performance of high-technology firms. Academy of Management Journal, 49(3), 544-560. https://doi.org/10.5465/amj.2006.21794671

14. Datta, D. K., Guthrie, J. P., \& Wright, P. M. (2005). Human resource management and labor productivity: Does industry matter. Academy of Management Journal, 48(1), 135-145. https://doi.org/10.5465/amj.2005.15993158

15. Dewinne, S., \& Sels, L. (2010). Interrelationships between human capital, HRM and innovation in Belgian start-ups aiming at an innovation strategy. The International Journal of Human Resource Management, 21(11), 1863-1883. https://doi.org/10.1080/09585192.2010.505088

16. Eisenhardt, K. M. \& Martin, J. A. (2000). Dynamic capabilities: What are they? Strategic Management Journal, 21(10), 1105-1121. https://doi.org/10.1002/1097-0266(200010/11)21:10/11<1105::AID-SMJ133>3.0.CO;2-E

17. Ferreira, J., \& Coelho, A. (2020). Dynamic capabilities, innovation and branding capabilities and their impact on competitive advantage and SME's performance in Portugal: The moderating effects of entrepreneurial orientation. International Journal of Innovation Science, 12(3), 255-286. https://doi.org/10.1108/IJIS-10-2018$\underline{0108}$

18. Fornell, C., \& Larcker, D. F. (1981). Evaluating structural equation models with unobservable variables and measurement error. Journal of Marketing Research,18(1), 39-50. https://doi.org/10.1177/0022243 $\underline{78101800104}$

19. Giniuniene, J., \& Jurksiene, L. (2015). Dynamic capabilities, innovation and organizational learning: Interrelations and impact on firm performance. Procedia-Social and Behavioral Sciences, 213, 985-991. https://doi.org/10.1016/j.sbspro.2015.11.515

20. Guthrie, J. P., Flood, P. C., Liu, W., \& MacCurtain, S. (2009). High performance work systems in Ireland: Human resource and organizational outcomes. The International Journal of Human Resource Management, 20(1), 112-125. https://doi.org/10.1080/09585190802528433

21. Hagedoorn, J., \& Duysters, G. (2002). External sources of innovative capabilities: The preferences for strategic alliances or mergers and acquisitions. Journal of Management Studies, 39(2), 167-188. https://doi.org/10.1111/1467-6486.00287

22. Hair Jr, J. F., Hult, G. T. M., Ringle, C., \& Sarstedt, M. (2016). A primer on partial least squares structural equation modeling (PLS-SEM). Sage Publications. https://doi.org/10.15358/9783800653614

23. Hair, J. F., Black, W. C., Babin, B. J., Anderson, R. E., \& Tatham, R. (2006). Multivariate data analysis. Upper saddle River.

24. Heffernan, M., \& Dundon, T. (2016). Cross-level effects of high-performance work systems (HPWS) and employee well-being: The mediating effect of organizational justice. Human Resource Management Journal, 26(2), 211-231. https://doi.org/10.1111/1748-8583.12095

25. Heider, A., Gerken, M., van Dinther, N., \& Hülsbeck, M. (2021). Business model innovation through dynamic capabilities in small and medium enterprises-Evidence from the German Mittelstand. Journal of Business Research, 130, 635-645. https://doi.org/10.1016/j.jbusres.2020.04.051

26. Helfat, C. E., \& Raubitschek, R. S. (2018). Dynamic and integrative capabilities for profiting from innovation in digital platform-based ecosystems. Research Policy, 47(8), 1391-1399. https://doi.org/10.1016 j.jespol.2018.01.019

27. Huang, L. C., Ahlstrom, D., Lee, A. Y. P., Chen, S. Y., \& Hsieh, M. J. (2016). High performance work systems, employee well-being, and job involvement: An empirical study. Personnel Review, 45(2), 296-314. https://doi.org/10.1108/PR-09-2014-0201

28. Kintana, M. L., Alonso, A. U., \& Olaverri, C. G. (2006). High-performance work systems and firms' operational performance: the moderating role of technology. The International Journal of Human Resource Management, 17(1), 70-85. https://doi.org/10.1080/09585190500366466

29. Kuzma, E., Padilha, L. S., Sehnem, S., Julkovski, D. J., \& Roman, D. J. (2020). The relationship between innovation and sustainability: A meta-analytic study. Journal of Cleaner Production, 259, 120745 https://doi.org/10.1016/j.jclepro.2020.120745

30. Lepak, D. P., \& Snell, S. A. (2002). Examining the human resource architecture: The relationships among human capital, employment, and human resource configurations. Journal of Management, 28(4), 517-543. https://doi.org/10.1177/014920630202800403

31. Lin, Y. T., \& Liu, N. C. (2016). High performance work systems and organizational service performance: The roles of different organizational climates. International Journal of Hospitality Management, 55, 118-128. https://doi.org/10.1016/j.ijhm.2016.04.005 
32. Lu, C. M., Chen, S. J., Huang, P. C., \& Chien, J. C. (2015). Effect of diversity on human resource management and organizational performance. Journal of Business Research,68(4), 857-861. https://doi.org/10.101 6/j.jbusres.2014.11.041

33. Macky, K., \& Boxall, P. (2007). The relationship between 'high-performance work practices and employee attitudes: An investigation of additive and interaction effects. The International Journal of Human Resource Management, 18(4), 537-567. https://doi.org/10.1080/09585190601178745

34. Madsen, E. L. (2010). A dynamic capability framework-generic types of dynamic capabilities and their relationship to entrepreneurship. In Strategic reconfigurations: Building dynamic capabilities in rapidinnovation-based industries (pp. 223-241).

35. Medeiros, S. A. D., Christino, J. M. M., Gonçalves, C. A., \& Gonçalves, M. A. (2020). Relationships among dynamic capabilities dimensions in building competitive advantage: A conceptual model. Gestão \& Produção, 27(1), 1-15. https://doi.org/10.1590/0104-530x3680-20

36. Michaelis, B., Wagner, J. D., \& Schweizer, L. (2015). Knowledge as a key in the relationship between highperformance work systems and workforce productivity. Journal of Business Research, 68(5), 1035-1044. https://doi.org/10.1016/j.jbusres.2014.10.005

37. Muisyo, P. K., \& Qin, S. (2021). Enhancing the firm's green performance through green HRM: The moderating role of green innovation culture. Journal of Cleaner Production, 289, 125720. https://doi.org/10.10 16/j.jclepro.2020.125720

38. Naldi, L., Wikström, P., \& Von Rimscha, M. B. (2014). Dynamic capabilities and performance: An empirical study of audiovisual producers in Europe. International Studies of Management \& Organization, 44(4), 63-82. https://doi.org/10.2753/IMO0020-8825440404

39. Nunnally, J. C. (1994). Psychometric Theory 3 E. Tata McGraw-Hill Education.

40. Özçelik, G., Aybas, M., \& Uyargil, C. (2016). High performance work systems and organizational values: Resource-based view considerations. Procedia-Social and Behavioral Sciences, 235, 332-341. https://doi.org/10.1016/j.sbspro.2016.11.040

41. Podsakoff, P. M., MacKenzie, S. B., Lee, J. Y., \& Podsakoff, N. P. (2003). Common method biases in behavioral research: A critical review of the literature and recommended remedies. Journal of Applied Psychology, 88(5), 879-903. https://doi.org/10.1037/0021-9010.88.5.879

42. Ringle, C. M., Wende, S., \& Will, A. (2005). SmartPLS 2.0 (Beta). Hamburg, Germany: University of Hamburg.

43. Shih, H. A., Chiang, Y. H., \& Hsu, C. C. (2013). High performance work system and HCN performance. Journal of Business Research, 66(4), 540-546. https://doi.org/10.1016/j.jbusres.2012.01.002

44. Sriviboon, C. (2020). The impact of strategic human resource on the innovation performance of pharmacy companies in Thailand: Mediating role of innovation capabilities. Systematic Reviews in Pharmacy, 11(1), 434442.

45. Teece, D. J., Pisano, G., \& Shuen, A. (1997). Dynamic capabilities and strategic management. Strategic Management Journal, 18(7), 509-533. https://doi.org/10.1002/(SICI)1097-0266(199708)18:7<509::AIDSMJ882>3.0.CO;2-Z

46. Wang, W., Cao, Q., Qin, L., Zhang, Y., Feng, T., \& Feng, L. (2019). Uncertain environment, dynamic innovation capabilities and innovation strategies: A case study on Qihoo 360. Computers in Human Behavior, 95, 284-294. https://doi.org/10.1016/j.chb.2018.06.029

47. Xin, J., Song, C., Fuji, X., \& Zexia, L. (2018). Multi-dimensional influence of dynamic capabilities on innovation performance in knowledge-intensive service enterprises. Science Journal of Business and Management, 6(4), 81-92. https://doi.org/10.11648/j.sjbm.20180604.11

48. Zanko, M., Badham, R., Couchman, P., \& Schubert, M. (2008). Innovation and HRM: Absences and politics. The International Journal of Human Resource Management, 19(4), 562-581. https://doi.org/10.1 080/09585190801953616

49. Zehir, C., Gurol, Y., Karaboga, T., \& Kole, M. (2016). Strategic human resource management and firm performance: The mediating role of entrepreneurial orientation. Procedia-Social and Behavioral Sciences, 235 , 372-381. https://doi.org/10.1016/j.sbspro.2016.11.045

50. Zhang, M., Zhu, C. J., Dowling, P. J., \& Bartram, T. (2013). Exploring the effects of high-performance work systems (HPWS) on the work-related well-being of Chinese hospital employees. The International Journal of Human Resource Management, 24(16), 3196-3212. https://doi.org/10.1080/09585192.2013.775026 